\title{
Vibrio tapetis-like strain isolated from introduced Manila clams Ruditapes philippinarum showing symptoms of brown ring disease in Norway
}

\author{
Christine Paillard ${ }^{1, *}$, Kjetil Korsnes ${ }^{2,3}$, Patrick Le Chevalier ${ }^{4}$, Christine Le Boulay $^{4}$, \\ Lisbeth Harkestad ${ }^{2}$, Anne Grete Eriksen ${ }^{2}$, Endre Willassen ${ }^{5}$, Øivind Bergh ${ }^{2,6}$, \\ Clément Bovo ${ }^{1}$, Cecilie Skår ${ }^{2}$, Stein Mortensen ${ }^{2}$ \\ ${ }^{1}$ Institut Universitaire Européen de la Mer (IUEM). LEMAR. UMR 6539. Université de Bretagne Occidentale, \\ 29280 Plouzané, France \\ ${ }^{2}$ Institute of Marine Research, PO Box 1870, Nordnes, 5817 Bergen, Norway \\ ${ }^{3}$ Bodø University College, 8049 Bodø, Norway \\ ${ }^{4}$ Laboratoire Universitaire de Microbiologie Appliquée de Quimper (LUMAQ) IUT de génie biologique, \\ Université de Bretagne Occidentale, 29334 Quimper, France \\ ${ }^{5}$ The Natural History Collections, and ${ }^{6}$ Department of Biology, PO Box 7800, 5020 Bergen, Norway
}

\begin{abstract}
The Manila clam Ruditapes philippinarum was introduced to Norway in 1987 and was produced in 2 hatcheries until 1991. Clam seed was planted at 6 sites. Two sites were on the Island of Tysnes, south of Bergen. Surviving adult Manila clams were recovered in 1995 and 1996. In the present study, Manila clams from the original seeding that displayed morphological signs of brown ring disease (BRD) were recovered in June $2003(n=7)$ and in June $2004(n=17)$. Samples from extrapallial fluid, tissues and haemolymph were inoculated on marine agar. Replicate subcultures on selective media were used to select potential Vibrio tapetis strains, and in total, 190 bacterial strains were isolated. One of these strains clustered within the $V$. tapetis clade and was named NRP 45. DNA:DNA hybridisation with the type strain CECT4600 showed 52.7 and $57.3 \%$ DNA:DNA similarity. Hybridisation of NRP 45 and the V. tapetis LP2 strain, isolated from corkwing wrasse Symphodus melops, produced 46.6 and $44.4 \%$ re-association. Partial gene segments encoding $16 \mathrm{~S}$ rRNA, gyrase B protein (GyrB) and chaperonin 60 protein (Cpn60) were characterised and compared to CECT 4600. NRP 45 showed 5 differences in the 1416 nucleotides (nt) of the 16S rRNA encoding gene (99.6\% similarity), while the GyrB encoding gene had 62 substitutions of 1181 nt compared (94.8\% similarity) and the Cpn60 encoding gene had 22 substitutions out of $548 \mathrm{nt}$ compared (96\% similarity). This is the first finding of BRD and the first isolation of a $V$. tapetis-like bacterial strain from a bivalve in Norway.
\end{abstract}

KEY WORDS: Brown ring disease $\cdot$ Vibrio tapetis $\cdot$ Bivalve $\cdot$ Manila clams $\cdot$ Bacteria $\cdot$ Norway

\section{INTRODUCTION}

The Manila clam Ruditapes philippinarum (Adams \& Reeve 1850), which is originally from Asia, has been introduced to many areas in North America and Europe. In many cultivation areas, the Manila clam has been severely affected by brown ring disease $(B R D$; reviewed by Paillard 2004). BRD is a bacterial shell disease, caused by Vibrio tapetis (Paillard \& Maes 1990, Borrego et al. 1996). The symptom characterising this disease is an abnormal conchiolin deposit, which generally adheres to the inner shell between the pallial line and the growth edge of the shell, forming the characteristic brown ring (Paillard et al. 1989). The Manila clam was introduced to France in 1972, and BRD appeared for the first time in clam beds in Brittany (France) in 1987. The 
disease has subsequently spread along the East Atlantic coast from England to North Africa (Paillard 2004). BRD was first observed in Spain in 1994, in England in 1997 and in Ireland in 1998 (Paillard \& Maes 1994, Castro et al. 1996, Novoa et al. 1998). The highest prevalence is encountered in the northernmost countries, and BRD is generally classified as a coldwater disease (Paillard et al. 1994). In Norway, the Manila clam was introduced in 1987 (Mortensen \& Strand 2000). Approximately 500 broodstock specimens were imported from Scottish Seafarms Ltd to 2 Norwegian hatcheries, located in Espevik on the Island of Tysnes, south of Bergen, and in Vallersund in South Trøndelag County (Fig. 1A). From 1987 to 1991, more than 200 million seed were produced, with ongrowth done in nurseries at Espevik, Rong, Vallersund and Vågstanda. Most of the Manila clam seed were exported to Spain and Ireland. In Espevik, the native clam $R$. decussatus was also produced by the same methods and during the same period as the Manila clams. Clam production was terminated in 1991. Between 1988 and 1991, Manila clam seed were released on beaches at 6 sites. At Seløy (Fig.1B), approximately 2000 Manila clam spat were released in 1988, and a total of 28 specimens were recaptured in 1995 (Mortensen \& Strand 2000). The objective of the present study was to investigate if survivors of Manila clams planted along Seløy in 1988 exhibit clinical signs of BRD and harbour $V$ tapetis strains.

\section{MATERIALS AND METHODS}

Sampling site. Seløy is a small island outside the island of Tysnes, in Hordaland County, south of Bergen, Norway $\left(59^{\circ} 55^{\prime} \mathrm{N}, 5^{\circ} 43^{\prime} \mathrm{E}\right)$. The sampling was performed in the Seløy poll (lagoon) at the south side of the island (Fig. 1A). This site consists of a sheltered, relatively small poll with a maximum depth of approximately $5 \mathrm{~m}$, a narrow channel with a slow tidal current, and a sheltered bay as an entrance to the outside fjord (Fig. 1B). The poll has been used as a traditional, heliothermic oyster poll in conjunction with intensive flat oyster culture carried out in the nearby Espevik poll and nursery. There are at present few bivalves in the Seløy poll, probably due to relatively dense populations of predator species such as wrasse, eel and shore crabs. The channel has a sand and gravel substrate, suitable for cockles and clams with a moderate density of these species.

Clam sampling and identification. In May 2003, Manila clams were collected in a restricted area by digging from the upper $15 \mathrm{~cm}$ of the substrate in the sandy part of the tidal current, and were kept on ice until dissection in the laboratory. In June 2004, sampling for Manila clams was conducted in the whole narrow channel and also along the shoreline around the poll by diving. All recovered Manila clams and native clam species were identified by morphological features of shells and soft parts, as described by Cesari

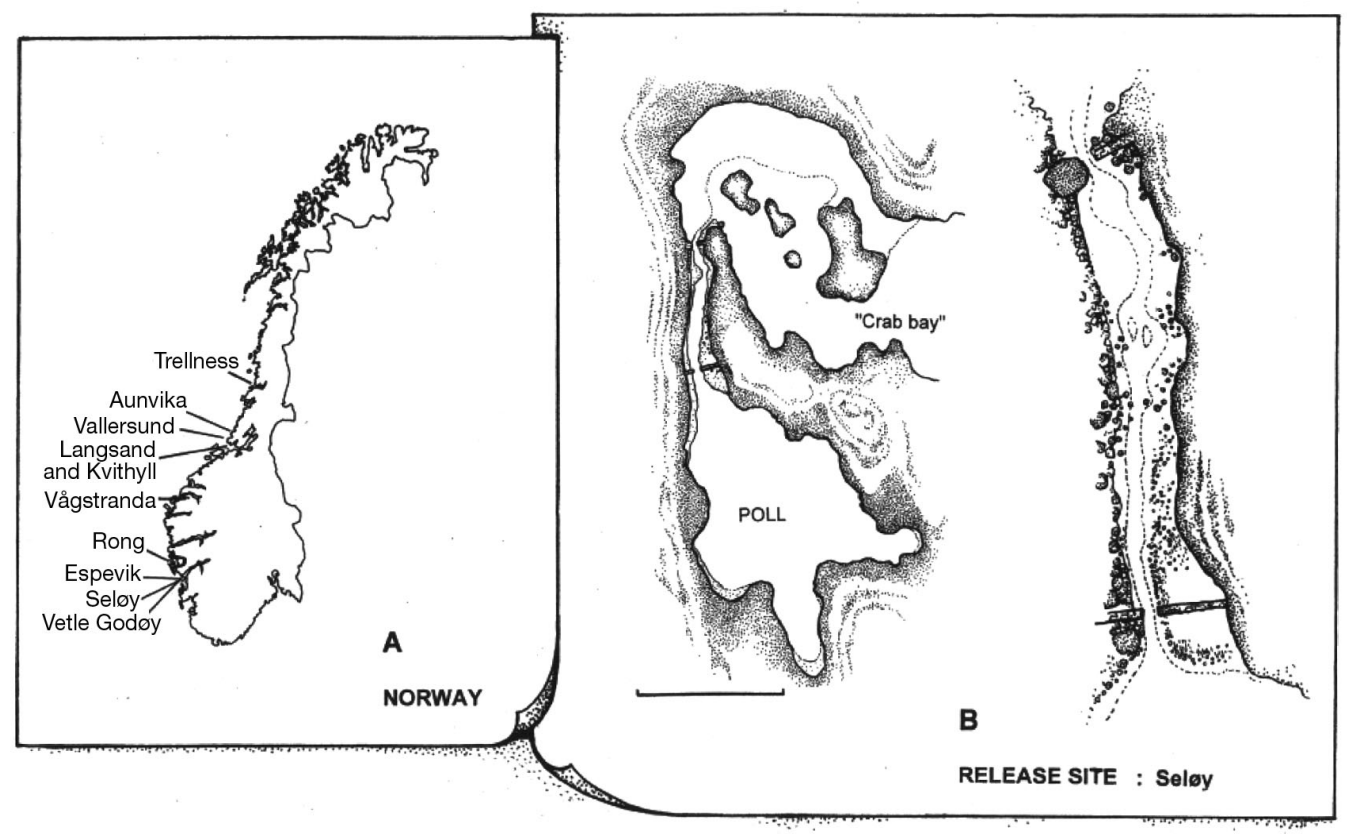

Fig. 1. (A) Manila clams Ruditapes philippinarum were originally imported to hatcheries at Vallersund and Espevik, produced in nurseries at Vallersund, Vågstranda, Rong and Espevik, and seeded at Trellnes, Aunvika, Langsand and Kvithyll, Vetle Godøy and Seløy. (B) Sampling site at Seløy consisting of a poll (lagoon), a shallow tidal stream and an outside bay facing the fjord. The tidal current (enlarged) runs into a partially man-made channel. Clams were sampled in the widest part of the channel. 
\& Pellizato (1990) and Holme (1961). Shell length of Manila clams was measured with callipers to the nearest $\mathrm{mm}$, and age was determined from growth rings according to Johannessen (1973).

BRD diagnostics. Development and/or recovery of BRD were judged by scaling macroscopic symptoms according to the classification system established by Paillard \& Maes (1994), with modifications by Paillard (2004).

Bacterial isolation protocol. Bacteria were isolated from extrapallial fluid (EPF; Paillard et al. 2006), digestive gland and mantle (Allam et al. 1996). Briefly, serial dilutions of EPF, digestive gland and mantle suspensions were prepared in sterile seawater (SSW). Serial dilutions $(0.1 \mathrm{ml})$ were plated on Difco marine agar and incubated for $72 \mathrm{~h}$ at $20^{\circ} \mathrm{C}$. Total heterotrophic bacteria (THB) concentrations were counted and are presented as colony-forming units (CFU) $\mathrm{ml}^{-1}$ or $^{-1}$ fresh weight of whole clams. The selection of isolates carried forward for further analyses was performed according to Maes \& Paillard (1992). Briefly, replicate subcultures on selective media were used to select potential Vibrio tapetis strains, based on 4 important characteristics: non-utilisation of sucrose and mannitol, growth on thiosulfate citrate bile sucrose (TCBS) agar, and failure to grow above $30^{\circ} \mathrm{C}$. Colonies meeting these 4 requirements were isolated and purified, and then subjected to phenotypic, serological and molecular characterisation as described below.

Phenotypic characterisation. A series of biochemical tests were carried out using commercial API 20E and API 50CH kits (Bio-Merieux). The tests were conducted according to the manufacturer's protocol, with the following exceptions: with the API 20E Kit, bacteria were suspended in autoclaved, 30 ppt seawater. Bacte- ria were suspended in the medium provided by the supplier for the API 50CH kit that had been adjusted to a final salinity of 20 ppt using $\mathrm{NaCl}$. Kits were then incubated at $20^{\circ} \mathrm{C}$ and read for $48 \mathrm{~h}$ prior to interpreting each test strip. Bacterial surface antigen properties were addressed by using an agglutination assay using a polyclonal antiserum (Pasteur Institute), raised in a rabbit against cells of Vibrio tapetis strain IS1. Prior to agglutination, bacteria were cultured for $72 \mathrm{~h}$, and colonies that developed on marine agar were harvested in $0.5 \mathrm{ml} \mathrm{SSW}$. Finally, $5 \mu \mathrm{l}$ of an anti- $V$. tapetis (CECT 4600) polyclonal antibody solution (Pasteur Institute) were added for visual observation of agglutination. An antibody against V. cholerae (Pasteur Institute) was used as a negative control.

PCR amplification and sequencing. Using the protocol described by Paillard et al. (2006), all bacterial strains were screened using specific primers for Vibrio tapetis. This screening was used to select strains for further characterisation. DNA from the isolated strain was extracted with a DNAeasy Tissue Kit (Qiagen) according to the manufacturer's instructions, and stored at $-20^{\circ} \mathrm{C}$. Selected type strains of Vibrio spp. were subject to PCR amplification of 16S rRNA (Weisburg et al. 1991), GyrB (Yamamoto \& Harayama 1995) and Cpn60 (Rusanganwa et al. 1992) partial gene fragments. The bacteria included in this study are summarised in Table 1. All PCR reactions used approximately $100 \mathrm{ng}$ DNA in a $20 \mu \mathrm{l}$ reaction and were performed with an ABI 9700 thermal cycler (Applied Biosystems). PCR amplification of the 16S rRNA encoding gene was performed with final reaction concentrations of $1.5 \mathrm{mM} \mathrm{MgCl} 2,0.2 \mathrm{mM}$ of each dNTP, $0.5 \mu \mathrm{M}$ of each primer and 1 unit Taq polymerase (Promega). The temperature conditions consisted of an

Table 1. Bacterial strains and accession numbers for all sequences included in the phylogenetic analysis

\begin{tabular}{|lccc|}
\hline Strain & 16S rRNA & Gyrase B (GyrB) & Chaperonin 60 (Cpn60) \\
\hline NRP 45 & AM402968 & AM399070 & AM399071 \\
Vibrio tapetis CECT4600 & Y08430 & AM162571 & AM162561 \\
Vibrio tapetis LP2 & AY129278 & AM162570 & AM162560 \\
Vibrio lentus CIP 107166 & AM162659 & AM162564 & AM162554 \\
Vibrio chagasii LMG 21353 & AJ490157 & AM162568 & AM162558 \\
Vibrio splendidus LP1 & AY129277 & AM235734 & AM235733 \\
Vibrio fischeri NCMB 1281 & AY292923 & AY455874 & AM235730 \\
Vibrio parahaemolyticus NCMB 1902 & AF388387 & AM235735 & AM235731 \\
Vibrio kanaloae LMG 20539 & AM162657 & AM162563 & AM162553 \\
Vibrio cyclitrophicus LMG 21359 & AM162656 & AM162562 & AM162552 \\
Listonella anguillarum strain 610 & AM162655 & AM162569 & AM162559 \\
Listonella anguillarum NCMB 6 & AM235737 & AM235736 & AM235732 \\
Aeromonas salmonicida subsp. salmonicida NCBM 1102 & AB027541 & AY294485 & DQ074967 \\
Photobacterium damsela & AY147857 & AJ249850 & AF230942 \\
Pseudomonas fluorescens & DQ178230 & NC004129 & NC007492 \\
Escherichia coli K12 & U00096 & U00096 & U00096 \\
\hline
\end{tabular}


initial denaturation step of $95^{\circ} \mathrm{C}$ for $5 \mathrm{~min}$, followed by 30 cycles of $94^{\circ} \mathrm{C}$ for $1 \mathrm{~min}, 55^{\circ} \mathrm{C}$ for $1 \mathrm{~min}$ and $72^{\circ} \mathrm{C}$ for $1 \mathrm{~min}$, and a final extension at $72^{\circ} \mathrm{C}$ for $10 \mathrm{~min}$. PCR amplification of Cpn60 was performed with final reaction concentrations of $1.88 \mathrm{mM} \mathrm{MgCl}_{2}, 0.25 \mathrm{mM}$ of each dNTP, $0.25 \mu \mathrm{M}$ of each primer and 1 unit Taq polymerase (Promega). Thermocycling consisted of an initial denaturation step of $95^{\circ} \mathrm{C}$ for $5 \mathrm{~min}$, followed by 35 cycles of $95^{\circ} \mathrm{C}$ for $1 \mathrm{~min}, 55^{\circ} \mathrm{C}$ for $1 \mathrm{~min}$ and $72^{\circ} \mathrm{C}$ for $2 \mathrm{~min}$, and a final extension hold at $72^{\circ} \mathrm{C}$ for $10 \mathrm{~min}$. PCR amplification of GyrB was performed with final reaction concentrations of $1.88 \mathrm{mM} \mathrm{MgCl}_{2}, 0.25 \mathrm{mM}$ of each dNTP, $0.25 \mu \mathrm{M}$ of each primer and 2.5 units Taq polymerase (Promega). Thermocycling consisted of an initial denaturation step of $95^{\circ} \mathrm{C}$ for $5 \mathrm{~min}$, followed by 35 cycles of $95^{\circ} \mathrm{C}$ for $1 \mathrm{~min}, 58^{\circ} \mathrm{C}$ for $1 \mathrm{~min}$ and $72^{\circ} \mathrm{C}$ for $2 \mathrm{~min}$, and a final extension at $72^{\circ} \mathrm{C}$ for $7 \mathrm{~min}$.

Sequencing was performed using the ABI Prism ${ }^{\mathrm{TM}}$ Big-Dye $^{\text {TM }}$ Terminator Cycle Sequencing Ready Reaction Kit version 3.1 (Applied Biosystems), and reactions were analysed on an ABI PRISM ${ }^{\circledR} 3700$ DNA Analyzer (Applied Biosystems). The gene fragments were assembled into complete sequences in ContigExpress in the Vector NTI Advance 9.0 computer package (Invitrogen). The 16S rRNA encoding gene sequence was BLAST-searched for nucleotide-nucleotide matches in the National Center for Biotechnology Information (NCBI) database (www.ncbi.nlm.nih.gov/BLAST/) to establish initial strain identity (Altschul et al. 1990). The 16S rRNA, GyrB and Cpn60 sequences obtained were submitted to GenBank (accession nos. AM402968, AM399070 and AM399071, respectively).

DNA:DNA hybridisation. DNA:DNA hybridisation of NRP 45 and Vibrio tapetis type strain CECT 4600 and $V$. tapetis strain LP2 was performed by the DSMZ laboratory (Braunschweig, Germany). DNA was isolated using a French pressure cell (Thermo Spectronic) and was purified by chromatography on hydroxyapatite as described by Cashion et al. (1977). DNA:DNA hybridisation was carried out as described by De Ley et al. (1970), with modifications described by Huss et al. (1983), using a model Cary 100 Bio ultraviolet-visible (UV/VIS)-spectrophotometer equipped with a Peltierthermostatted $6 \times 6$ multicell changer and a temperature controller with an in situ temperature probe (Varian). Re-association was carried out in $2 \times$ saline sodium citrate (SSC) at $67^{\circ} \mathrm{C}$, and the percentage of re-hybridisation was calculated.

Phylogenetic inference. Phylogenetic analyses of a selection of bacteria were performed, using the $16 \mathrm{~S}$ rRNA, GyrB and Cpn60 partial gene fragments obtained from GenBank. The alignments were manually adjusted using the sequence alignment editors GeneDoc (Nicholas et al. 1997) and BIOEDIT (Hall 1999). Genetic distance calculations and phylogenetic tree estimations under maximum parsimony (MP) and maximum likelihood (ML) were made with PAUP* (Swofford 1998). Hierarchical log-likelihood ratio testing was performed with Modeltest version 3.7 (Posada \& Crandall 1998) to infer the best evolutionary model for ML estimates of phylogenetic trees (Posada \& Crandall 2001). Similar procedures were followed with MrModeltest version 2.2 (Nylander 2004) in order to infer appropriate model settings and prior probability definitions for Bayesian analysis with MrBayes3 (Ronquist \& Huelsenbeck 2003). The Bayesian computation was done by 2 parallel runs, each with 4 Markov chains sampling parameter states every 200 of 2 million generations in total. The 'burn-in' was performed on 19700 trees. Phylogenetic inference was made from each gene fragment separately and additionally from a concatenated matrix of the alignments from each gene. Parsimony and ML heuristic searches were executed with 100 replicate random additions of sequences and with the TBR algorithm and MulTrees in effect (Swofford 1998). Branch support was calculated under MP with 250 bootstrap replicates. Tree graphics were made with utilities in Mesquite (Maddison \& Maddison 2004) and Adobe Photoshop ${ }^{\circledR}$.

\section{RESULTS}

Recovery of clams at Seløy. In total, 24 Manila clams were recovered at the Seløy poll (Fig. 1B), including 7 individuals in May 2003 and 17 in June 2004. The Manila clams measured 46 to $62 \mathrm{~mm}$, weighed 33 to $66 \mathrm{~g}$ and were estimated to be $15 \mathrm{yr}$ old. No juvenile Manila clams were found. A total of 12 individuals were female, 6 were males and 6 had undifferentiated gonads.

BRD diagnostics. In May 2003, the BRD prevalence in Manila clams was $71 \%$ (5 were diseased and 2 had completely recovered). In the diseased clams, the conchiolin stages varied between the individuals examined, depending on the shell repair stages (SRS); 3 had the lowest conchiolin deposit stage (CDS 1 or 2), and 2 showed extensive development of BRD signs (CDS 4 and 7). The majority of diseased clams exhibited signs of a shell repair process, and observations suggested the clams to be in various stages of this process (Fig. 2). In contrast, the clams collected in June 2004 had a lower prevalence of BRD: only 1 clam displayed morphological BRD signs (BRD prevalence $=6 \%$ ), and 7 clams had recovered completely (recovery prevalence $=41 \%$ ).

Isolation and characteristics of bacteria. Total heterotrophic bacterial microflora (THBM) varied between individuals: digestive gland bacterial loads ranged from $10^{4}$ to $4.3 \times 10^{5} \mathrm{CFU} \mathrm{g}^{-1}$ while those in extrapallial fluids ranged from $1.4 \times 10^{3}$ to $1.4 \times$ 


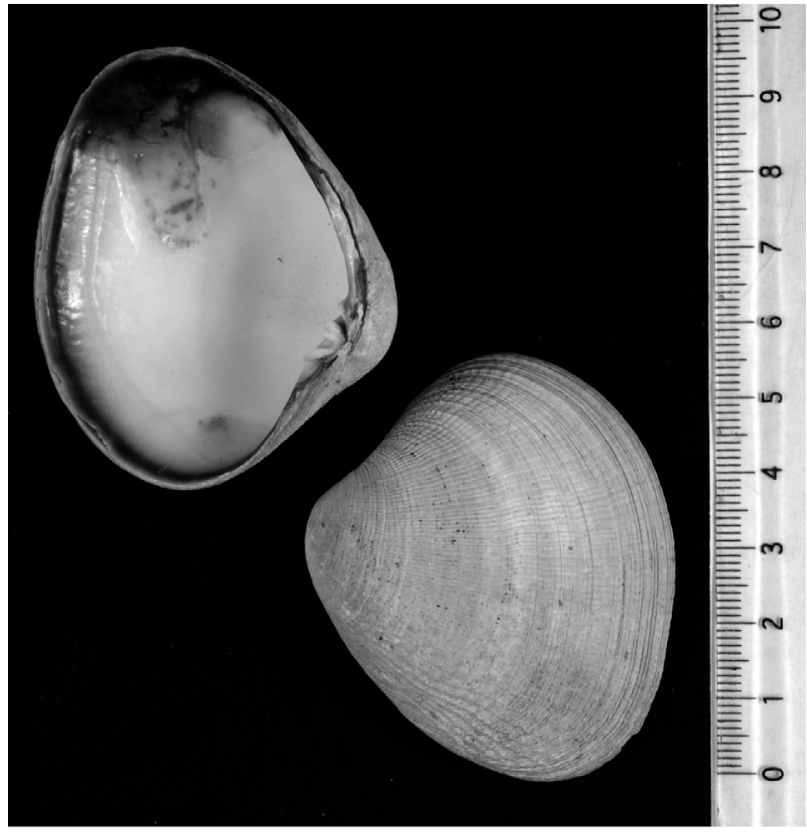

Fig. 2. Ruditapes philippinarum. Manila clam from Seløy, Norway, with characteristic brown ring symptoms showing recovery (shell repair stage $=2.5$ ) on the inner shell surface. Scale bar is in $\mathrm{cm}$

$10^{6} \mathrm{CFU} \mathrm{ml}{ }^{-1}$. In one clam, a similar abundance of bacteria to the extrapallial fluid was found in the mantle $\left(3 \times 10^{4} \mathrm{CFU} \mathrm{^{-1 }}\right)$. After using selective methods, i.e. growth on thiosulfate citrate bile sucrose (TCBS) agar, mannitol, temperature of $30^{\circ} \mathrm{C}$, agglutination tests and species-specific primed (SSP)-PCR identification, only 1 strain fulfilled the criteria defined for Vibrio tapetis. This strain was isolated from a plating of extrapallial fluid from 1 clam collected in May 2003 showing signs of shell repair (SRS $=2.5$ ). According to colony morphology on marine agar (MA) and MA supplemented
Table 2. Important biochemical characteristics distinguishing the type strain CECT 4600 and strain NRP 45 by using API 20E and API 50CH. AMY: AMYgdaline; DXYL: D-XYLose

\begin{tabular}{|lcc|}
\hline Biochemical property & $\begin{array}{r}\text { Type strain } \\
\text { CECT } 4600\end{array}$ & Strain NRP 45 \\
\hline Mannitol & - & + \\
AMY & - & + \\
Indole production & - & + \\
Cellobiose & - & + \\
DXYL & - & + \\
\hline
\end{tabular}

with mannitol, this strain was the dominant bacterium from the primary isolation on MA and was harvested after $48 \mathrm{~h}$. The colony morphology on these media was similar to that of V. tapetis type strain CECT 4600 as both produced green (sucrose negative) colonies on TCBS media and did not grow at $30^{\circ} \mathrm{C}$. The isolated strain was given the strain identity NRP 45 .

Phenotypic characterisation. The NRP 45 strain showed differences in 5 biochemical properties compared to the type strain CECT 4600 (Table 2). The agglutination assay revealed agglutination in strain NRP 45 when specific antibodies (against Vibrio tapetis CECT 4600) were used, and no agglutination in the control antiserum.

PCR product and sequencing. Using primers targeting the genes 16S rRNA, GyrB and Cpn60, the sizes of the PCR products were approximately 1500, 1200 and 600 nucleotides (nt), respectively. Sequence comparison of the 16S rRNA-encoding gene from strain NRP 45 (AM402968) and the type strain CECT 4600 (Y08430) revealed $99.6 \%$ similarity in the 1416 nt compared. Comparison of GyrB partial gene sequences from NRP 45 (AM399070) and CECT 4600 (AM162571) revealed $94.8 \%$ similarity, with 62 substitutions in the sequence

Table 3. Summary of phylogenetic analyses based on nucleotide sequences from 3 genes in Vibrio and other bacteria. The maximum parsimony (MP) score includes steps in uninformative sites. The TrN model (Tamura \& Nei 1993) assumes unequal base frequencies and 3 rate categories, K80 (Kimura 1980) assumes equal base frequencies and 2 rates; SYM (symmetrical) assumes equal base frequencies and 6 rates, and GTR is the general time reversible model with unequal base frequencies and 6 rates. G means that rate heterogeneity over the sequences is modelled with the gamma function, and I additionally models invariable

sites. p-dist: proportion of nucleotide sites at which 2 sequences being compared are different; ML: maximum likelihood

\begin{tabular}{|lcccc|}
\hline & 16S rRNA & Cpn60 & GyrB & All \\
\hline Alignment positions & 1358 & 483 & 1137 & 2978 \\
Mean p-dist (variance) & $0.062(0.002)$ & $0.180(0.005)$ & $0.213(0.005)$ & - \\
Parsimony informative sites & 164 & 170 & 453 & 787 \\
Number of MP trees & 1 & 550 & 1 & 3 \\
Number of minimum steps & 556 & K80+G & SYM+I+G & TrN+I+G \\
Model used in ML search & TrN+I+G & -3037.52 & -8248.51 & -16209.42 \\
Log likelihood score & -4533.25 & $($ SYM+G+I) & (SYM+G+I) & Mixed \\
Model used in Bayesian search & $($ GTR+G+I) & & & \\
\hline
\end{tabular}




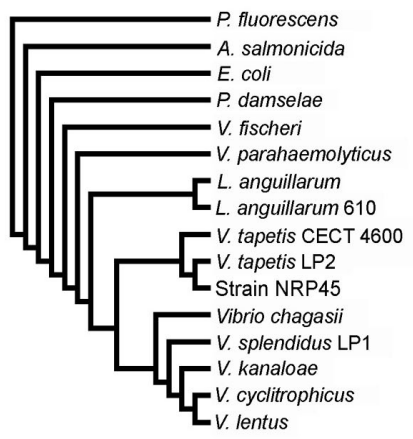

A

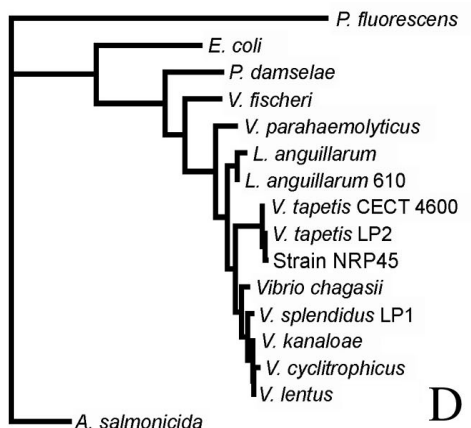

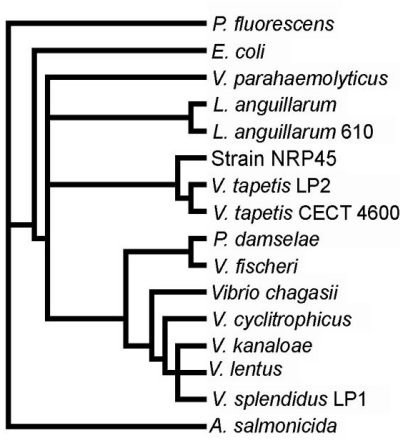

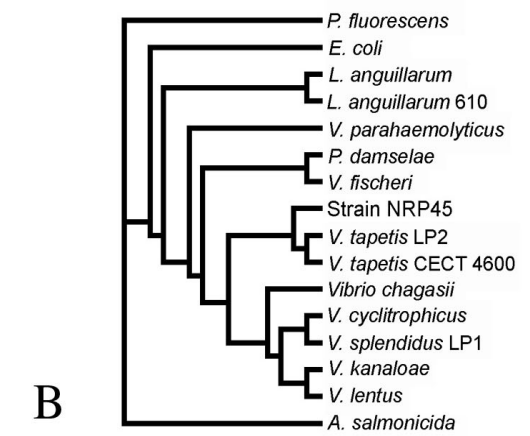

C

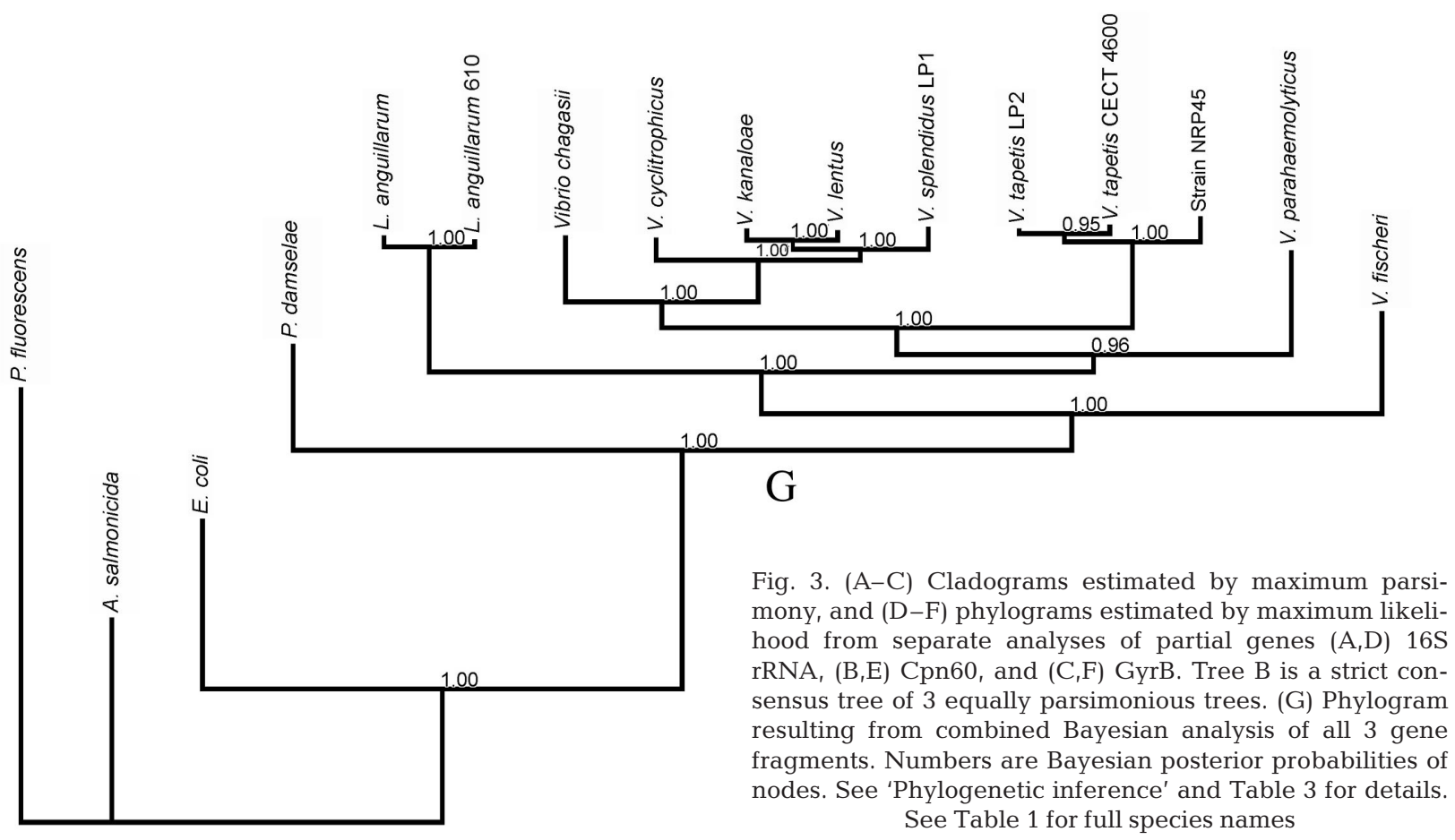

of $1181 \mathrm{nt}$ compared. Comparison of $548 \mathrm{nt}$ of the Cpn60 partial gene fragment revealed 96\% similarity, where strain NRP 45 (AM399071) showed substitutions in 22 positions compared to CECT 4600 (AM162561).

Phylogenetic analysis. Separate analyses of each gene (Table 3) with MP produced slightly different tree topologies (Fig. 3A-C), but the closest phyloge- netic relationship between NRP 45 and the Vibrio tapetis strains was indicated by all gene fragments with $100 \%$ bootstrap support. ML searches based on model settings and parameter settings inferred with Modeltest 3 (Table 3) returned results that were congruent with the MP tree with respect to the placement of strain NPR 45 (Fig. 3D-F). 
The concatenated matrix of 3 gene fragments using ML criterion returned a tree with the same topology as the Bayesian reconstruction (Fig. 3G) with mixed models (Table 3). The Bayesian computation returned a posterior probability of $100 \%$ for NPR 45 being at the base of the Vibrio tapetis clade. Thus, the evidence from combined analysis of 3 genes suggests that strain NPR 45 diverged from the most recent common ancestor of the LP2 and CECT 4600 strains of $V$. tapetis.

DNA:DNA hybridisation. DNA:DNA hybridisation of strain NRP 45 and the Vibrio tapetis type strain CECT 4600 revealed re-hybridisation percentages of 52.7 and $57.3 \%$ in 2 replicate hybridisations. The hybridisation of NRP 45 and $V$. tapetis LP2 strain returned 46.6 and $44.4 \%$.

\section{DISCUSSION}

We report the first identification of a Vibrio tapetislike strain in Manila clams exhibiting clinical signs of BRD in Norway. In the present work, the Manila clams recovered coincided with both the original seeding in 1988 (Mortensen \& Strand 2000) and the recovery in 1995. No spat or young specimens were found during our study in 2003 and 2004. Therefore, there is still no indication of an establishment of this species in the Norwegian fauna.

Macroscopical features on the inner bivalve shell surface are used as indicators of abnormal or disturbed shell growth. A brownish conchiolin deposit is a characteristic feature associated with BRD (Paillard et al. 1989). These organic deposits, which may be found both in Ruditapes philippinarum and $R$. decussatus, are a result of a defence reaction and are not exclusively due to the presence of the BRD causative agent Vibrio tapetis (Paillard 2004). Other parasites, like fungi, annelids and trematodes, also disturb the pallial edge by shell boring, irritating the epithelium or living within the mantle tissue (Paillard et al. 1994, 1996). Because of the non-specificity of the symptoms, BRD must always be verified by $V$. tapetis detection. The strain NRP 45 showed 99.6\% 16S rRNA similarity to the $V$. tapetis CECT 4600 reference strain, 94.8\% GyrB similarity and $96 \%$ Cpn60 similarity. Nucleotide differences in the Cpn60 fragments were all in synonymous codons when NPR 45 was compared to the $V$. tapetis strains. However, the GyrB differences affected a minimum of 5 nonsynonymous sites, of which 2 involved amino acids with similar physiochemical characteristics (D vs. E, and I vs. V). In contrast to sequence similarities, the mean result from DNA:DNA hybridisation was $55 \%$, which is below the species threshold level of $70 \%$ suggested by Wayne et al. (1987). Thus, the strain NRP 45, although clearly related genomically and serologically, as well as with respect to important biochemical characteristics, should not be assigned to the species $V$. tapetis based on the threshold criterion. DNA:DNA hybridisation with the $V$. tapetis strain LP2, isolated from wrasse in Norway, showed an average result of approximately $45 \%$. This further supports that NRP 45 should not be regarded as a $V$. tapetis strain. The high 16S rDNA similarity found demonstrates that this gene alone does not allow discrimination between closely related strains or species. As illustrated by the phylogenetic analysis (Fig. 3), the strain clustered within the $V$. tapetis clade and should be termed $V$. tapetis-like.

It is not known whether strains closely related to NRP 45 or Vibrio tapetis were already present in the environment when the clams were seeded at Seløy. BRD symptoms might have been overlooked during previous samplings, during the production in Espevik from 1989 to 1992 (Mortensen 1993). During sampling at Seløy and the nearby Vetle Godøy in 1995 (Mortensen \& Strand 2000), no diagnostic tests for $V$. tapetis were carried out. Except for 1 isolation of $V$. tapetis LP2 from 1 fish species, the corkwing wrasse Symphodus melops (Jensen et al. 2003), this bacterium has not previously been found in Norway. Thus, the origin of $V$. tapetis-like bacteria in Seløy is not known. There are apparently at least 2 possibilities explaining its presence. One possibility is that $V$. tapetis-like strains were introduced with Manila clams in 1987. If this is the case, Espevik may represent an important site, as the centre of previous Manila clam production. Between 1988 and 1992, a large biomass of Ruditapes philippinarum and $R$. decussatus was present in Espevik during the hatchery and nursery operations (Mortensen 1993, Strand 1996). The nursery and a semi-recirculation system, using poll water as a food source (Strand 1996), are particularly interesting from a zoosanitary point of view. Any pathogenic agent present in clams, or other bivalve species in the nursery or in the poll, would have had time and opportunity to become established in susceptible or vector species present, or within the environment. The Manila clams from Seløy were originally hatched and nursed at this site and could therefore have been exposed to a number of bacteria, either indigenous or introduced from other areas. Following the seeding, few primary hosts for $V$. tapetis-like bacteria were available at Seløy. After seeded clams died, and since no more clams have been introduced in these waters, we presume that the availability of hosts has been low. However, V. tapetis might have colonised new hosts, and other clam species such as Tapes pullastra could potentially harbour this pathogen (Paillard et al. 1989, Maes \& Paillard 1992). The cockle Cardium edule has been recognised as a reservoir species (Maes \& Paillard 1992, Paillard 
2004 ) and could also potentially contribute to the persistence of $V$. tapetis at the site. The other possibility is that NRP 45 represents an indigenous bacterial species, which colonises indigenous host species, such as several clam species and cockles. A coevolution process between strains like NRP 45 or $V$. tapetis and native bivalves might have occurred in many areas in Europe. The introductions of Manila clams might then have represented the exposure of a new, highly susceptible host, resulting in the described BRD outbreaks.

During the present sampling, only a few bacterial samples were taken from native Ruditapes decussatus, from which Vibrio tapetis or $V$. tapetis-like bacteria were not detected (authors' unpubl. data). A more thorough sampling should therefore be carried out in Seløy, Espevik and at clam sites where Manila clams have not been present, in order to clarify the possible presence of $V$. tapetis and $V$. tapetis-like bacteria in the indigenous Norwegian bivalve fauna.

Acknowledgements. This study was financially supported by the AURORA-programme, jointly financed by the Norwegian Research Council, the French Ministry of Foreign Affairs and the French Ministry of Education (Research and Technology), the French National Coastal Ecosystem Program (PNEC) and French Regional Interest Research Program (PRIR), Laboratoire Universitaire de Microbiologie Appliquée de Quimper (France), Environmental Marine Science Laboratory (LEMAR) in Université de Bretagne Occidentale (France), Bodø University College (Norway) and Institute of Marine Research (Norway). Thanks to Alf Roald Sætre for valuable historical data and information and to Eivind Bergtun for accommodation during the fieldwork. The authors also thank Claire Sintes, Nelly Le Goïc, Erwann Amice and Kristin Hopkins for technical assistance.

\section{LITERATURE CITED}

Adams A, Reeve L (1850) Mollusca. In: Adams A (ed) The zoology of the voyage of the H.M.S. Samarang: under the command of Captain Sir Edward Belcher. Reeve, Benham, and Reeve, London, p 1-87

Allam B, Paillard C, Maes P (1996) Localization of the pathogenic Vibrio P1 in clams affected by Brown Ring Disease. Dis Aquat Org 27:149-155

Altschul SF, Gish W, Miller W, Myers EW, Lipman DJ (1990) Basic local alignment search tool. J Mol Biol 215:403-410

Borrego JJ, Castro D, Luque A, Paillard C, Maes P, Garcia MT, Ventosa A (1996) V. tapetis sp. nov., the causative agent of the brown ring disease affecting cultured clams. Int J Syst Bacteriol 46:480-484

Cashion P, Hodler-Franklin MA, McCully J, Franklin M (1977) A rapid method for base ratio determination of bacterial DNA. Anal Biochem 81:461-466

Castro D, Santamaria JA, Luque A, Martinez-Manzanares E, Borrego JJ (1996) Antigenic characterization of the etiological agent of the brown ring disease affecting manila clams. Syst Appl Microbiol 19:231-239

Cesari P, Pellizzato M (1990) Biology of Tapes philippinarum. In: Entedi Sviluppo Agricolo Veneto (ESAV). Tapes phillipinarum biologia e sperimentazione. Pubblicatione curata dal Settore Pesca e Acquacoltura, Trieste, p 21-46

De Ley J, Cattoir H, Reynaerts A (1970) The quantitative measurement of DNA hybridization from renaturation rates. Eur J Biochem 12:133-142

Hall TA (1999) Bioedit: a user friendly biological sequence alignment editor and analysis program for Windows 95/98/NT. Nucleic Acids Symp Ser 41:95-98

Holme NA (1961) Shell form in Venerupis rhomboides. J Mar Biol Assoc UK 41:705-722

Huss VAR, Fesl H, Schleifer KH (1983) Studies on the spectrophotometric determination of DNA hybridization from renaturation rates. Syst Appl Microbiol 4:184-192

Jensen S, Samuelsen OB, Andersen K, Torkildsen L and others (2003) Characterization of strains of Vibrio splendidus and V. tapetis isolated from corkwing wrasse Symphodus melops suffering vibriosis. Dis Aquat Org 53:25-31

Johannessen $\mathrm{OH}$ (1973) Population structure and individual growth of Venerupis pullastra (Montagu) (Lamellibranchia). Sarsia 52:97-116

Kimura M (1980) A simple method for estimating evolutionary rate of base substitution through comparative studies of nucleotide sequences. J Mol Evol 16:111-120

Maddison WP, Maddison DR (2004) Mesquite: a modular system for evolutionary analysis. Version 1.05. Available at: http://mesquiteproject.org

Maes P, Paillard C (1992) Effect du Vibrio P1, pathogène de Ruditapes philippinarum, sur d'autres espèces de bivalves. Les mollusques marins, biologies et aquaculture. IFREMER. Actes Colloq 14:141-148

Mortensen SH (1993) A health survey of selected stocks of commercially exploited Norwegian bivalve molluscs. Dis Aquat Org 16:149-156

Mortensen SH, Strand Ø (2000) Releases and recaptures of Manila clams (Ruditapes philippinarum) introduced to Norway. Sarsia 85:87-91

Nicholas KB, Nicholas HB, Deerfield DW (1997) GeneDoc: analysis and visualization of genetic variation. EMBNEW.NEWS 4:14

Novoa B, Luque A, Castro D, Borrego JJ, Figueras A (1998) Characterization and infectivity of four bacterial strains isolated from brown ring disease-affected clams. J Invertebr Pathol 71:34-41

Nylander JAA (2004) MrModeltest version 2.2. Evolutionary Biology Center, University of Uppsala, published by the author. Available at: www.ebc.uu.se/systzoo/staff/ nylander.html

> Paillard C (2004) Review of brown ring disease, a vibriosis affecting clams. Aquat Living Resour 17:467-475

Paillard C, Maes P (1990) Étiologie de la maladie de l'anneau brun chez Tapes philippinarum: pathogenicité d'un Vibrio sp. C R Acad Sci Paris Serie III Sci Vie 310:15-20

Paillard C, Maes P (1994) Brown ring disease in the Manila clam Ruditapes philippinarum: establishment of a classification system. Dis Aquat Org 19:137-146

Paillard C, Percelay L, Le Pennec M, Le Picard D (1989) Origine pathogène de l'anneau brun' chez Tapes philippinarum (Mollusque, bivalve). CR Acad Sci Paris Serie III Sci Vie 309:235-241

Paillard C, Maes P, Oubella R (1994) Brown ring disease in clams. Annu Rev Fish Dis 4:219-240

Paillard C, Ashton-Alcox K, Ford SE (1996) Changes in bacterial densities and hemocyte parameters in oysters affected by juvenile oyster disease. Aquat Living Resour 9:145-158

> Paillard C, Gausson S, Nicolas JL, Le Pennec JP, Haras D (2006) Molecular identification of $V$. tapetis, the causative 
agent of the brown ring disease of Ruditapes philippinarum. Aquaculture 253:25-38

Posada D, Crandall KA (1998) MODELTEST: testing the model of DNA substitution. Bioinformatics 14:817-818

Posada D, Crandall KA (2001) Selecting the best-fit model of nucleotide substitution. Syst Biol 50:580-601

Ronquist F, Huelsenbeck JP (2003) MrBayes 3: Bayesian phylogenetic inference under mixed models. Bioinformatics 19:1572-1574

Rusanganwa E, Singh B, Gupta RS (1992) Cloning of HSP60 (GroEL) operon from Clostridium perfringens using a polymerase chain reaction based approach. Biochim Biophys Acta 1130:90-94

Strand $\varnothing$ (1996) Enhancement of the bivalve production capacity in a landlocked heliothermic marine basin. Aquacult Res 27:355-373

Swofford DL (1998) PAUP*: phylogenetic analysis using par-

Editorial responsibility: Mike Hine,

Fouras, France simony ( ${ }^{*}$ and other methods), version 4 . Sinauer, Sunderland, MA

Tamura K, Nei M (1993) Estimation of the number of nucleotide substitutions in the control region of mitochondrial-DNA in humans and chimpanzees. Mol Biol Evol 10:512-526

Wayne LG, Brenner DJ, Colwell RR, Grimont PAD and others (1987) Report of the ad-hoc-committee on reconciliation of approaches to bacterial systematics. Int J Syst Bacteriol $37: 463-464$

Weisburg WG, Barns SM, Pelletier DA, Lane DJ (1991) 16S ribosomal DNA amplification for phylogenetic study. J Bacteriol 173:697-703

Yamamoto S, Harayama S (1995) PCR amplification and direct sequencing of GyrB genes with universal primers and their application to the detection and taxonomic analysis of Pseudomonas putida strains. Appl Environ Microbiol 61:1104-1109

Submitted: October 15, 2007; Accepted: June 13, 2008

Proofs received from author(s): August 22, 2008 